\title{
Currarino Syndrome: lower urinary tract function, treatment plan and outcomes.
}

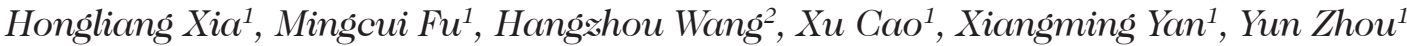 \\ and Jian Wang ${ }^{3}$ \\ ${ }^{1}$ Department of Urology, Children's Hospital of Soochow University, Suzhou, China. \\ ${ }^{2}$ Department of Neurosurgery, Children's Hospital of Soochow University, Suzhou, \\ China. \\ ${ }^{3}$ Department of General Surgery, Children's Hospital of Soochow University, Suzhou, \\ China.
}

Key words: Currarino syndrome (CS); video-urodynamics (VUDS); neurogenic bladder; children; multidisciplinary.

\begin{abstract}
Currarino syndrome (CS) is a rare congenital disorder characterized by anorectal malformation, sacral agenesis and presacral mass. We performed video-urodynamics (VUDS) assessment of patients with CS to characterize the lower urinary tract function, individualize management plans and to follow outcomes. We conducted a cross-sectional study on 11 patients diagnosed with CS at the spina bifida multidisciplinary clinic. Lower urinary tract function was assessed by VUDS from three months to 12 months after neurosurgery. All patients had sacral agenesis; nine patients had anorectal malformation $(9 / 11,81.8 \%)$ and five patients had a presacral mass $(5 / 11,45.5 \%)$. The average age at neurosurgery was 7.9 months (range, 2-19). One patient had bilateral vesicoureteral reflux (VUR) with increasing detrusor pressure at the end of filling. In two patients, the detrusor activity showed weakening during urination, while no other lower urinary tract abnormality was identified on urodynamic evaluation. Six patients underwent VUDS before and after surgery; of these, two patients showed improved bladder function after surgery, while the remaining four patients showed no change in urodynamies. The average duration of follow-up was 27.5 months (range, 9-51). Renal function was normal in all patients. We can conclude that patients with CS often exhibit associated neurological abnormalities. VUDS assessment may help detect lower urinary tract dysfunction at an early stage and facilitate timely urological intervention to avoid kidney damage.
\end{abstract}

Corresponding author: Jian Wang . Department of General Surgery, Children's Hospital of Soochow University, Suzhou, China. E-mail :wanǵ.medical23@gmail.com 


\title{
Síndrome de Currarino: función del tracto urinario inferior, plan de tratamiento y resultados.
}

\author{
Invest Clin 2021; 62 (2): 103-111
}

Palabras clave: síndrome de Currarino (SC); videourodinámica (VUDS); vejiga neurógena; niños; multidisciplinario.

Resumen. El síndrome de Currarino (SC) es un trastorno congénito poco común que se caracteriza por malformación anorrectal, agenesia sacra y masa presacra. Realizamos una evaluación por video-urodinamia (VUDS) de pacientes con SC para caracterizar la función del tracto urinario inferior, planes de manejo individualizados y el seguimiento terapéutico posterior. Realizamos un estudio transversal en 11 pacientes diaǵnosticados de SC en la clínica multidisciplinaria de espina bífida. La función del tracto urinario inferior se evaluó mediante VUDS de 3 a 12 meses después de la neurocirugía. Todos los pacientes tenían agenesia sacra; nueve pacientes tenían malformación anorrectal $(9 / 11$, $81,8 \%)$ y cinco pacientes tenían una masa presacra $(5 / 11,45,5 \%)$. La edad promedio en el momento de la neurocirugía fue de 7,9 meses (rango, 2-19). Un paciente tenía reflujo vesicoureteral (RVU) bilateral con aumento de la presión del detrusor al final del llenado. En dos pacientes, la actividad del detrusor mostró debilitamiento durante la micción, mientras que no se identificó ninguna otra anomalía del tracto urinario inferior en la evaluación urodinámica. Seis pacientes se sometieron a VUDS antes y después de la cirugía; de estos, dos pacientes mostraron una mejor función de la vejiga después de la cirugía, mientras que los cuatro pacientes restantes no mostraron cambios en la urodinámica. La duración media del seguimiento fue de 27,5 meses (rango, 9-51). La función renal fue normal en todos los pacientes. Podemos concluir que los pacientes con SC suelen presentar anomalías neurológicas asociadas. La evaluación de VUDS puede ayudar a detectar la disfunción del tracto urinario inferior en una etapa temprana y facilitar la intervención urológica oportuna para evitar daño renal.

Received: 13-11-2020 Accepted: 23-01-2021

\section{INTRODUCTION}

Currarino syndrome (CS) is a rare autosomal dominant genetic disease, which was first described by Currarino et al. in 1981 (1). The cardinal characteristics of CS include sacral agenesis, anorectal malformation and a presacral mass (also referred to as the Currarino triad) $(2,3)$. The presacral mass, which may lead to sacral nerve compression or traction, is usually a my- elomeningocele, lipomyelomeningocele, or teratoma; in rare cases, the mass may be a lipoma or an enterogenous eyst. CS may be associated with intraspinal abnormalities, such as filum terminal lipoma, intraspinal dermoid cyst, or intraspinal lipoma, leading to tethered cord (TC). Therefore, patients with CS may exhibit signs of sacral nerve dysfunction, such as constipation, lower urinary tract symptoms, and lower limb sensorimotor deficit $(2,3)$. 
Patients with CS (especially those who require neurosurgery for correction of neural tube closure defect and release of TC) require evaluation of lower urinary tract function, urological treatment, and follow-up of renal function. Urological evaluation and treatment of children with spina bifida has been shown to prevent renal damage and improve life expectancy and quality of life (4). Apart from ultrasound, magnetic resonance imaging and renal function tests, video-urodynamies (VUDS) is a particularly useful approach for assessment of lower urinary tract function and to predict the possibility of upper urinary tract injury in these patients (5). Till date, only a few case reports have described urological intervention in patients with CS $(6,7)$.

In this study, we retrospectively analyzed the urological evaluation and treatment of patients with CS who underwent neurosurgery at our spina bifida multidisciplinary clinic. Our experience may help promote individualized management of patients with CS with the objective to better preserve the upper urinary tract function.

\section{MATERIALS AND METHODS}

\section{Patient selection}

This was a cross-sectional study on patients diagnosed with CS at the spina bifida multidisciplinary clinic between 2014 and 2018. The diagnostic criteria for patients enrolled in our study were presence of sacral agenesis in combination with one or more of the following: presacral mass, anorectal malformation, genitourinary malformation, or other malformations. Data pertaining to medical history, clinical characteristics, investigations (ultrasound, maǵnetic resonance imaging (MRI), renal function tests and VUDS) and treatment outcomes were reported.

\section{Surgical treatment}

In the spina bifida multidisciplinary clinic, the general surgeons determined the necessity of surgical treatment of anorectal malformation, while the neurosurgeons determined the necessity of surgical treatment of the presacral mass, spina bifida, and/or TC. After the surgical protocol was determined by the general surgeon and the neurosurgeon, the urologist evaluated the patient's urinary system before and after surgery.

\section{VUDS assessment}

We performed comprehensive VUDS examination of patients, including cystometry, imaging (X-ray) monitoring, and sphineter electromyography. Data obtained from the examination included: bladder volume, bladder compliance, detrusor activity, detrusor leak-point pressure (DLPP) or end-filling pressure (EFP), detrusor-sphincter synergy, bladder morphology, and presence or absence of vesicoureteral reflux (VUR).

\section{Classification of bladder risk}

We classified the bladder status into four categories according to the urodynamic classification method proposed by Joseph (8) and Routh et al. (4): (1) highh-risk bladder: EFP/DLPP $\geq 40 \mathrm{~cm} \mathrm{H}_{2} \mathrm{O}$, or neurogenic detrusor overactivity (NDO) with detrusor sphincter dyssynergia (DSD); (2) intermediate-risk bladder: NDO, decreased bladder compliance, $25 \mathrm{~cm} \mathrm{H}_{2} \mathrm{O} \leq \mathrm{EFP} / \mathrm{DLPP}<40$ cm $\mathrm{H}_{2} \mathrm{O}$; (3) low-risk bladder (also known as safe bladder): EFP/DLPP $<25 \mathrm{~cm} \mathrm{H}_{2} \mathrm{O}$, detrusor contraction $<60 \mathrm{~cm}_{2} \mathrm{O}$ without DSD; (4) normal bladder: normal bladder volume, bladder compliance detrusor pressure change $<15 \mathrm{~cm} \mathrm{H}_{2} \mathrm{O}$, no NDO, no DSD, detrusor contraction $<60 \mathrm{~cm} \mathrm{H}_{2} \mathrm{O}$, normal post-void volume. We improved the classification method according to the VUDS examination. If grade I-IV VUR appeared during inspection, the risk may increase by one level. A high-risk bladder may be defined if V-level VUR get appeared.

\section{Urological management}

We used a combination of clean intermittent catheterization (CIC) and oral anti- 
cholinergiic drugs for highh-risk bladders, and guided urination training for patients with weakened detrusor activity during urination.

\section{Follow-up plan}

We developed a follow-up plan for all patients based on bladder risk and age. The follow-up plan included renal and bladder ultrasound (RBUS), VUDS, and renal function tests. Occurrence of lower urinary tract symptoms (such as a febrile urinary tract infection) during follow-up is an indication for immediate RBUS. In the event of detection of a new abnormality on RBUS, VUDS should be performed. Renal function tests were concomitantly performed with RBUS; renal function was calculated using the Schwartz serum creatinine clearance formula (9):

$$
\mathrm{eGFR}=\mathrm{kL} / \mathrm{SCr}
$$

where $\mathrm{k}$ is a constant ( $\mathrm{k}$ value is 0.33 for premature infants $<1$ year of age; 0.45 for fullterm infants $<1$ year of age; 0.55 for children aged 2-12 years and adolescent women aged 13-21 years; 0.7 for adolescent males aged 13-21 years). L refers to height $(\mathrm{cm})$, and $\mathrm{SCr}$ refers to serum creatinine $(\mathrm{mg} / \mathrm{dL})$.

\section{Statistical analysis:}

Descriptive statistics were used to report continues data by Mean \pm SD and categorical data by number and percent. No further analytical statistical analysis was conducted.

\section{RESULTS}

\section{Patient characteristics}

Our study included 11 patients (8 males, 3 females) with CS. The mean age at diagnosis was $7.3 \pm 5.2$ months (range, $0-19$ months). The characteristics of enrolled patients are summarized in Table I.

\section{Outcomes of general surgical treatment}

All 11 patients had sacral agenesis. Eight patients had anorectal malformations
$(8 / 11,72.72 \%)$; seven patients had congenital anal atresia, and one patient had anal stenosis. Among the other malformations, one patient had Hirschsprung disease. Of the seven patients with anal atresia, four patients had rectoperineal fistula. Out of the seven children with anal atresia, two were first diagnosed as CS at the spina bifida multidisciplinary clinic because of the complication of lipomyelomeningocele, while the remaining five patients were first diagnosed in the general surgery department. All seven patients underwent surgery within three days after birth (two underwent sigmoidostomy and five underwent anoplasty). Patients with stricture of anus underwent anoplasty at the age of five months. Patients with Hirschsprung underwent Pull-through Procedure at 6-month-old.

\section{Outcomes of neurosurgical treatment}

The average age of patients at the time of neurosurgery was $7.9 \pm 4.9$ months (range, 2-19). Sacrococeygeal MRI performed at the spina bifida multidisciplinary clinic revealed TC in six patients. Three patients had filum terminal lipoma, two patients had intraspinal masses (intraspinal dermoid eyst and intraspinal lipoma, respectively), and one patient had pilonidal sinus. All six patients underwent mass resection and $\mathrm{TC}$ release in neurosurgery. Five patients had presacral mass $(5 / 11,45.5 \%)$; of these, three patients had a lipomyelomeningocele, one had sacrococcygeal teratoma, and one had sacrococcygeal lipoma. Lipoma resection and neural tube reconstruction was performed in patients with lipomyelomeningocele. Tumor resection and $\mathrm{TC}$ release were performed in patients with sacrococeygeal lipoma and teratoma.

\section{Outcomes of urological evaluation and treatment}

All patients underwent VUDS examination at 3-12 months after neurosurgery. (Table II) Six patients underwent both preand post-operative VUDS. Of these, two pa- 
TABLE I

CHARACTERISTICS OF THE PATIENTS.

\begin{tabular}{|c|c|c|c|c|c|c|c|c|}
\hline No & ender & $\begin{array}{c}\text { Age at } \\
\text { diagnosis }\end{array}$ & $\begin{array}{c}\text { Sacral } \\
\text { agenesis }\end{array}$ & ARM & $\begin{array}{l}\text { Age at } \\
\text { ARM } \\
\text { surgery }\end{array}$ & Presacral mass & $\begin{array}{l}\text { Other } \\
\text { malformations }\end{array}$ & $\begin{array}{c}\text { Age at } \\
\text { Neurosurgery }\end{array}$ \\
\hline 1 & $\mathrm{~F}$ & $5 \mathrm{~m}$ & Yes & Anal atresia & $\begin{array}{l}5 \mathrm{~m} \\
2 \mathrm{~d}\end{array}$ & No & $\begin{array}{l}\text { Pilonidal sinus, } \\
\text { Right solitary } \\
\text { kidney }\end{array}$ & $6 \mathrm{~m}$ \\
\hline 2 & $\mathrm{~F}$ & $1 \mathrm{~d}$ & Yes & $\begin{array}{l}\text { Anal atresia } \\
\text { with fistula }\end{array}$ & $2 \mathrm{~d}$ & $\begin{array}{l}\text { Lipomyelo- } \\
\text { meningocele }\end{array}$ & Hydrocephalus & $3 \mathrm{~m}$ \\
\hline 3 & M & $7 \mathrm{~m}$ & Yes & Anal atresia & $2 \mathrm{~d}$ & No & $\begin{array}{l}\text { Intraspinal } \\
\text { dermoid cyst, } \\
\text { Craniostenosis, } \\
\text { Dextrocardia } \\
\text { with VSD }\end{array}$ & $7 \mathrm{~m}$ \\
\hline 4 & M & $11 \mathrm{~m}$ & Yes & $\begin{array}{l}\text { Anal atresia } \\
\text { with fistula }\end{array}$ & $1 \mathrm{~d}$ & No & $\begin{array}{c}\text { Intraspinal } \\
\text { lipoma, } \\
\text { Syringomyelia }\end{array}$ & $11 \mathrm{~m}$ \\
\hline 5 & M & $8 \mathrm{~m}$ & Yes & No & No & $\begin{array}{c}\text { Sacrococcygeal } \\
\text { lipoma }\end{array}$ & No & $8 \mathrm{~m}$ \\
\hline 6 & M & $13 \mathrm{~m}$ & Yes & $\begin{array}{l}\text { Anal atresia } \\
\text { with fistula }\end{array}$ & $1 \mathrm{~d}$ & No & $\begin{array}{l}\text { Filum terminal } \\
\text { lipoma }\end{array}$ & $13 \mathrm{~m}$ \\
\hline 7 & $\mathrm{~F}$ & $19 \mathrm{~m}$ & Yes & $\begin{array}{c}\text { Rectal } \\
\text { stenosis }\end{array}$ & $5 \mathrm{~m}$ & No & $\begin{array}{l}\text { Filum terminal } \\
\text { lipoma }\end{array}$ & $19 \mathrm{~m}$ \\
\hline 8 & M & $7 \mathrm{~m}$ & Yes & Anal atresia & $6 \mathrm{~m}, 1 \mathrm{~d}$ & No & $\begin{array}{l}\text { Filum terminal } \\
\text { lipoma }\end{array}$ & $7 \mathrm{~m}$ \\
\hline 9 & M & $6 \mathrm{~m}$ & Yes & $\begin{array}{c}\text { Hirschsprung } \\
\text { disease }\end{array}$ & $6 \mathrm{~m}$ & $\begin{array}{l}\text { Lipomyelo- } \\
\text { meningocele }\end{array}$ & $\begin{array}{l}\text { Left duplex } \\
\text { kidney }\end{array}$ & $9 \mathrm{~m}$ \\
\hline 10 & M & $2 \mathrm{~m}$ & Yes & No & No & $\begin{array}{c}\text { Sacrococeygeal } \\
\text { teratoma }\end{array}$ & Polydactyly & $2 \mathrm{~m}$ \\
\hline 11 & M & $1 \mathrm{~d}$ & Yes & $\begin{array}{l}\text { Anal atresia } \\
\text { with fistula }\end{array}$ & $3 \mathrm{~d}$ & $\begin{array}{l}\text { Lipomyelo- } \\
\text { meningocele }\end{array}$ & $\begin{array}{l}\text { Left solitary } \\
\text { kidney with } \\
\text { hydronephrosis, } \\
\text { Bilateral } \\
\text { cryptorchidism, } \\
\text { Right radial } \\
\text { deficiency }\end{array}$ & $2 \mathrm{~m}$ \\
\hline
\end{tabular}

ARM: anorectal malformation; m, months; d, days; VSD, ventricular septal defect.

tients who had intermediate-risk bladder on preoperative VUDS assessment (right grade III VUR and DLPP 28cm $\mathrm{H}_{2} \mathrm{O}$, respectively) showed low-risk bladder on postoperative VUDS assessment (resolution of right VUR and decrease of DLPP to $20 \mathrm{~cm} \mathrm{H}_{2} \mathrm{O}$, respec- tively). One patient had preoperative EFP 35 cm $\mathrm{H}_{2} \mathrm{O}$ with right grade II VUR, which was classified as high-risk bladder. This patient had postoperative EFP $44 \mathrm{~cm} \mathrm{H}_{2} \mathrm{O}$ with bilateral VUR (left grade II, right grade III), and worse postoperative lower urinary tract func- 
TABLE II

UROLOGICAL EVALUATION AND MANAGEMENT.

\begin{tabular}{|c|c|c|c|c|c|c|}
\hline No & $\begin{array}{l}\text { VUDS before } \\
\text { neurosurgery }\end{array}$ & Neurosurgery & $\begin{array}{l}\text { VUDS after } \\
\text { neurosurgery }\end{array}$ & $\begin{array}{c}\text { Urological } \\
\text { management }\end{array}$ & $\begin{array}{c}\text { Follow- } \\
\text { up(months) }\end{array}$ & $\begin{array}{c}\text { eGFR } \\
(\mathrm{mL} / \\
\left.\min / 1.73 \mathrm{~m}^{2}\right)\end{array}$ \\
\hline 1 & No & $\begin{array}{l}\text { Spinal cord } \\
\text { untethering }\end{array}$ & $\begin{array}{c}\mathrm{EFP} 10 \mathrm{~cm} \\
\mathrm{H}_{2} \mathrm{O}, \text { Low risk } \\
\text { bladder }\end{array}$ & RBUS once a year & 51 & 101.7 \\
\hline 2 & No & $\begin{array}{l}\text { Lipoma } \\
\text { resection and } \\
\text { neural placode } \\
\text { reconstruction }\end{array}$ & $\begin{array}{l}\text { DLPP } 18 \mathrm{~cm} \\
\mathrm{H}_{2} \mathrm{O}, \text { Low risk } \\
\text { bladder }\end{array}$ & RBUS once a year & 48 & 123.6 \\
\hline 3 & $\begin{array}{l}\text { EFP } 35 \mathrm{~cm} \\
\mathrm{H}_{2} \mathrm{O}, \text { Right } \\
\text { VUR, High } \\
\text { risk bladder }\end{array}$ & $\begin{array}{l}\text { Dermoid cyst } \\
\text { resection and } \\
\text { Spinal cord } \\
\text { untethering }\end{array}$ & $\begin{array}{c}\text { EFP44 cm } \\
\mathrm{H}_{2} \mathrm{O}, \text { Bilateral } \\
\text { VUR, High risk } \\
\text { bladder }\end{array}$ & $\begin{array}{l}\text { CIC }+ \\
\text { anticholinerǵics, } \\
\text { RBUS once every } \\
6 \text { m, VUDS once } \\
\text { a year }\end{array}$ & 42 & 109.1 \\
\hline 4 & $\begin{array}{l}\text { EFP } 5 \mathrm{~cm} \\
\mathrm{H}_{2} \mathrm{O}, \text { Low } \\
\text { risk bladder }\end{array}$ & Lipoma resection & $\begin{array}{l}\text { EFP } 11 \mathrm{~cm} \\
\mathrm{H}_{2} \mathrm{O}, \text { Low risk } \\
\text { bladder }\end{array}$ & RBUS once a year & 36 & 140.3 \\
\hline 5 & $\begin{array}{l}\text { EFP } 14 \mathrm{~cm} \\
\mathrm{H}_{2} \mathrm{O}, \text { Low } \\
\text { risk bladder }\end{array}$ & $\begin{array}{l}\text { Lipoma resection } \\
\text { and Spinal cord } \\
\text { untethering }\end{array}$ & $\begin{array}{c}\mathrm{EFP} 9 \mathrm{~cm} \\
\mathrm{H}_{2} \mathrm{O}, \text { Low risk } \\
\text { bladder }\end{array}$ & RBUS once a year & 33 & 102.5 \\
\hline 6 & $\begin{array}{c}\text { EFP } 18 \\
\text { cm } \mathrm{H}_{2} \mathrm{O}, \\
\text { Right VUR, } \\
\text { Intermediate } \\
\text { risk bladder }\end{array}$ & $\begin{array}{l}\text { Filum terminal } \\
\text { transection }\end{array}$ & $\begin{array}{c}\text { EFP } 24 \mathrm{~cm} \\
\mathrm{H}_{2} \mathrm{O}, \text { VUR } \\
\text { disappeared, } \\
\text { Low risk } \\
\text { bladder }\end{array}$ & $\begin{array}{l}\text { RBUS once every } \\
6 \mathrm{~m} \text {, VUDS once } \\
\text { every } 2 \mathrm{y}\end{array}$ & 24 & 128.1 \\
\hline 7 & $\begin{array}{c}\text { Detrusor } \\
\text { underactivity, } \\
\text { Low risk } \\
\text { bladder }\end{array}$ & $\begin{array}{l}\text { Filum terminal } \\
\text { transection }\end{array}$ & $\begin{array}{l}\text { Detrusor } \\
\text { underactivity, } \\
\text { Low risk } \\
\text { bladder }\end{array}$ & $\begin{array}{l}\text { Urination training, } \\
\text { RBUS once every } \\
6 \mathrm{~m} \text {, VUDS once } \\
\text { every } 2 \mathrm{y}\end{array}$ & 21 & 129.6 \\
\hline 8 & No & $\begin{array}{l}\text { Filum terminal } \\
\text { transection }\end{array}$ & $\begin{array}{l}\text { Detrusor } \\
\text { underactivity, } \\
\text { Low risk } \\
\text { bladder }\end{array}$ & $\begin{array}{l}\text { Urination training, } \\
\text { RBUS once every } \\
6 \mathrm{~m} \text {, VUDS once } \\
\text { every } 2 \mathrm{y}\end{array}$ & 15 & 109.8 \\
\hline 9 & No & $\begin{array}{l}\text { Lipoma } \\
\text { resection and } \\
\text { neural placode } \\
\text { reconstruction }\end{array}$ & $\begin{array}{c}\text { EFP } 7 \mathrm{~cm} \\
\mathrm{H}_{2} \mathrm{O}, \text { Low risk } \\
\text { bladder }\end{array}$ & RBUS once a year & 12 & 111.3 \\
\hline 10 & No & $\begin{array}{l}\text { Teratoma } \\
\text { resection }\end{array}$ & $\begin{array}{l}\text { EFP } 12 \mathrm{~cm} \\
\mathrm{H}_{2} \mathrm{O}, \text { Low risk } \\
\text { bladder }\end{array}$ & RBUS once a year & 12 & 104.7 \\
\hline 11 & $\begin{array}{c}\text { DLPP } 28 \\
\text { cm } \mathrm{H}_{2} \mathrm{O}, \\
\text { Intermediate } \\
\text { risk bladder }\end{array}$ & $\begin{array}{l}\text { Lipoma } \\
\text { resection and } \\
\text { neural placode } \\
\text { reconstructionn }\end{array}$ & $\begin{array}{l}\text { DLPP } 20 \mathrm{~cm} \\
\mathrm{H}_{2} \mathrm{O}, \text { Low risk } \\
\text { bladder }\end{array}$ & RBUS once a year & 9 & 93.7 \\
\hline
\end{tabular}

VUDS, video-urodynamies; DLPP, detrusor leak-point pressure; EFP, end-filling pressure, VUR, vesicoureteral reflux; RBUS, renal and bladder ultrasound. 
tion. This patient was treated with CIC and an oral anticholinergic drug (oxybutynin). In the remaining three patients, both pre- and post-operative VUDS revealed low-risk bladder. Five patients had undergone only postoperative VUDS. Two patients who showed low detrusor activity, prolonged urination but less residual urine during urination, were classified as low-risk bladder group. Both patients underwent urination training. VUDS results in the remaining three patients showed low-risk bladder.

\section{Outcomes of urology follow-up}

The follow-up plan for individual patients was based on the bladder risk (Table III). The mean follow-up time in the entire cohort was $27.5 \pm 14.5$ months (range, 9-51). One patient developed febrile urinary tract infection. No new abnormal manifestations were detected by ultrasound examination in any of the patients. One patient had a left solitary kidney with hydronephrosis and the symptoms were not aggravated. Renal function remained normal in all patients.

\section{DISCUSSION}

The embryological pathogenesis of CS was elaborated by Currarino et al. in 1981(1). In the early embryonic stage, the mesoderm extends to the tail to surround the notochord and form the vertebral body. Abnormal adhesions between the endoderm and neuroectoderm prevent the fusion of the vertebral body. Abnormal adhesion between the intestine formed by endoderm and the neural tube formed by the notochord leads to the main characteristic malformation of CS. The three main features of CS may not always manifest simultaneously. Sacral agenesis (the primary diagnostic criteria) may occur in combination with other malformations such as anorectal malformation, urinary malformation, reproductive system malformation, or nervous system malformation.

In addition to the Currarino triad, we observed the following malformations involving multiple systems in our cohort. Urinary system malformations: isolated kidney, hydronephrosis, renal duplication. Nervous

TABLE III

FOLLOW-UP PLAN OF UROLOGY DEPARTMENT.

\begin{tabular}{|c|c|c|}
\hline \multicolumn{3}{|c|}{ Multidisciplinary clinic after birth } \\
\hline \multicolumn{3}{|c|}{ Medical history, physical examination, spinal MRI, ultrasound } \\
\hline \multicolumn{3}{|c|}{$\begin{array}{c}\text { Multidisciplinary assessments in departments of general surgery, neurosurgery, } \\
\text { orthopedics, urology, and imaging. }\end{array}$} \\
\hline \multicolumn{3}{|c|}{ VUDS examination before and after operation } \\
\hline \multirow[t]{2}{*}{ High-risk bladder } & $\begin{array}{l}\text { Age }<12 \mathrm{~m}, \text { RBUS after } 3 \mathrm{~m}, \\
\text { VUDS after } 6 \mathrm{~m}\end{array}$ & $\begin{array}{l}\text { Occurrence of lower urinary tract } \\
\text { symptoms (such as a febrile urinary }\end{array}$ \\
\hline & $\begin{array}{l}\text { Age } \geq 12 \mathrm{~m}, \text { RBUS after } 6 \mathrm{~m}, \\
\text { VUDS after } 1 \text { year }\end{array}$ & $\begin{array}{l}\text { tract infection) during follow-up is an } \\
\text { indication for immediate RBUS. In the }\end{array}$ \\
\hline \multirow[t]{2}{*}{$\begin{array}{l}\text { Intermediate-risk } \\
\text { bladder }\end{array}$} & $\begin{array}{l}\text { Age }<12 \mathrm{~m}, \text { RBUS after } 3 \mathrm{~m}, \\
\text { VUDS after } 1 \text { year }\end{array}$ & $\begin{array}{l}\text { event of detection of a new abnormality } \\
\text { on RBUS, VUDS should be immediately }\end{array}$ \\
\hline & $\begin{array}{l}\text { Age } \geq 12 \mathrm{~m}, \text { RBUS after } 6 \mathrm{~m}, \\
\text { VUDS after } 2 \text { years }\end{array}$ & \\
\hline \multirow[t]{2}{*}{$\begin{array}{l}\text { Low-risk and normal } \\
\text { bladder }\end{array}$} & $\begin{array}{l}\text { Age }<12 \mathrm{~m} \text {, RBUS after } 6 \mathrm{~m} \text {, } \\
\text { VUDS after } 1 \text { year }\end{array}$ & \\
\hline & $\begin{array}{l}\text { Age } \geq 12 \mathrm{~m}, \text { RBUS after } 12 \mathrm{~m}, \\
\text { VUDS after } 2 \text { years }\end{array}$ & \\
\hline
\end{tabular}

VUDS, video-urodynamies; RBUS, renal and bladder ultrasound.

Vol. 62(2): 103 - 111, 2021 
system malformation: hydrocephalus, craniostenosis, TC, syringomyelia, intraspinal mass. Limb malformations: absence of radius, polydactyly. Genital malformations: cryptorchidism. Cardiovascular malformations: dextrocardia, ventricular septal defect. Therefore, other factors apart from the embryological abnormalities might lead to multiple malformations.

In our study, three patients with CS had lipomyelomeningocele and postoperative VUDS assessment revealed low-risk bladder in all of them. However, long-term followup of bladder function is required. Other causes of lower urinary tract dysfunction may include primary or secondary TC, sacral nerve development defect, intraspinal mass, sphincter complex injury during anoplasty, or nerve injury during neurosurgery.

The present study focuses on the urological evaluation and management of patients with CS. Lee et al. retrospectively analyzed the urinary symptoms and urodynamics before and after TC release in 14 patients with CS (6). Pio et al. reported the clinical symptoms, imaging findings, and urodynamies of 16 patients with CS (7). Our study used VUDS to evaluate the bladder function of patients with CS. The risk of bladder function was classified based on the results of VUDS. According to the severity of bladder risk, we performed individualized clinical management to protect renal function.

In 2007, Joseph developed a risk index for bladder based on urodynamic assessment comprising of DLPP, NDO, and DSD (8). Tarcan et al. proposed that the predictive sensitivity of DLPP $20 \mathrm{~cm} \mathrm{H}_{2} \mathrm{O}$ for upper urinary tract injury is higher than that of $40 \mathrm{~cm}$ $\mathrm{H}_{2} \mathrm{O}$ (10). However, there are several determinants of the risk of upper urinary tract injury in these patients. The bladder risk classification proposed by Joseph is an important tool to guide treatment decision-making for neurogenic bladder. However, the risk rating does not incorporate the results of imagen examination. Therefore, we incorporated the results of imaging examination in the risk classification of bladder. For grade I to IV VUR and/or lack of smoothness of the bladder wall, the bladder risk increases by one level. A high-risk bladder should be defined when V grade VUR occurs.

Based on our experience, we have developed a comprehensive multidisciplinary diagnostic, therapeutic, and long-term follow-up plan for these patients (Table III). We hope that this plan will provide a viable treatment for CS and all other diseases that may lead to neurogenic bladder disease.

Some limitations of this study should be acknowledged. First of all, CS is a rare disease, since the spina bifida multidisciplinary clinic was established in 2014, limited sample-sized patients with CS have received standardized and comprehensive treatment at our center. This low sample size has limited us to only perform a crosssectional study and no analytical assessment was possible. So, the proposed interpretations and approaches are concluded qualitatively, as there was a huge heterogeneity in terms of the differences in the disease manifestations, surgeries that patients received, and their urological managements. Secondly, patients enrolled in the study did not undergo systematic genetic studies. Thirdly, the follow-up time of patients in this study was relatively short, and the function of the lower urinary tract of patients with CS may change over time. Therefore, long-term follow-up is necessary. Finally, our study did not research the lower urinary tract symptoms. Since most of the patients were too young to receive systematic urination training, we were unable to assess the lower urinary tract symptoms, such as urgency or urinary incontinence. In addition, most of the symptoms were reported by the parent or the caregiver, which may have introduced an element of bias.

We conclude that CS has a complex phenotype. The diagnosis and treatment necessitates multidisciplinary collaboration. Urologists play an important role in protecting renal function, preventing progression 
to end-stage renal disease, and in prolonging life expectancy. Patients with CS often exhibit sacral nerve development abnormality or injury to sacral nerves. VUDS assessment may help detect lower urinary tract dysfunction before the onset of lower urinary tract symptoms. A comprehensive urological intervention plan should be formulated based on the results of VUDS assessment.

\section{ACKNOWLEDGEMENT}

General Project of Jiangsu Commission of Health (Grant No. H2017067), Project of Suzhou Science and Technology Plan (Grant No.SYSD2019117).

\section{REFERENCES}

1. Currarino G, Coln D, Votteler T. Triad of anorectal, sacral, and presacral anomalies. AJR Am J Roentgenol 1981;137:395-398.

2. Caro-Dominguez P, Bass J, Hurteau-Miller J. Currarino Syndrome in a fetus, infant, child, and adoleseent: spectrum of clinical presentations and imaging findings. Can Assoc Radiol J 2017;68:90-95.

3. Martucciello G, Torre M, Belloni E, Lerone M, Pini Prato A, Cama A, Jasonni V. Currarino syndrome: proposal of a diagnostic and therapeutic protocol. J PediatrSurg 2004;39:1305-1311.

4. Routh JC, Cheng EY, Austin JC, Baum MA, Gargollo PC, Grady RW, Herron AR, Kim SS, King SJ, Koh C J, Paramsothy P, Raman L, Schechter MS, Smith KA, Tanaka ST, Thibadeau $\mathrm{J} \mathrm{K}$, Walker WO, Wallis MC, Wiener JS, Joseph DB. Design and methodological considerations of the Centers for Disease Control and Prevention Urologic and Renal Protocol for the Newborn and Young Child with Spina Bifida. J Urol 2016;196:17281734.
5. Anding R, Smith $\mathrm{P}$, de Jong T, Constantinou C, Cardozo L, Rosier P. When should video and EMG be added to urodynamies in children with lower urinary tract dysfunction and is this justified by the evidence? ICI-RS 2014. Neurourol Urodyn 2016;35:331-335.

6. Lee NG, Gana R, Borer JG, Estrada CR, Khoshbin S, Bauer SB. Urodynamic findings in patients with Currarino syndrome. J Urol 2012;187:2195-2200.

7. Pio L, Piatelli G, Rossi A, Scarsi P, Merello E, Capra V, Cama A, Buffa P, Torre M. Urological outcome in patients with Currarino syndrome. J Pediatr Surg 2014;49:16431646.

8. Joseph DB. Untethering of the spinal cord in children with myelomeningocele: effect on bladder function. Nat Clin Pract Urol 2007;4:472-473.

9. White CA, Akbari A. The estimation, measurement, and relevance of the glomerular filtration rate in stage 5 chronic kidney disease. Semin Dial 2011;24:540-549.

10. Tarean T, Sekerci CA, Akbal C, Tinay I, Tanidir Y, Sahan A, Sahin B, Top T, Simsek F. Is $40 \mathrm{~cm} \mathrm{H}_{2} \mathrm{O}$ detrusor leak point pressure cut-off reliable for upper urinary tract protection in children with myelodysplasia? Neurourol Urodyn 2017;36:759-763. 